\title{
Iron metabolism and human ferritin heavy chain cDNA from adult brain with an elongated untranslated region: new findings and insights ${ }^{\dagger}$
}

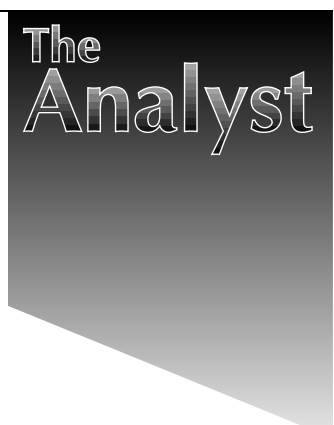

\author{
Maire E. Percy ${ }^{*} a$, Simon Wong ${ }^{a}$, Sharon Bauer ${ }^{a}$, Negin Liaghati-Nasseri ${ }^{a}$, Marc D. Perry ${ }^{b}$, \\ Vijay M. Chauthaiwale ${ }^{c}$, Madhu Dhar ${ }^{c}$ and Jayant G. Joshic \\ a Department of Physiology, University of Toronto and Surrey Place Centre, 2 Surrey Place, \\ Toronto, Ontario, Canada M5S 2C2 \\ ${ }^{b}$ Department of Molecular and Medical Genetics, University of Toronto, Toronto, Ontario, \\ Canada M5S 1 A8
}

c Department of Biochemistry, University of Tennessee, Knoxville, TN 37996, USA

Ferritin is a ubiquitous protein which plays a major role in iron sequestration, detoxification and storage. In this paper we highlight the role of ferritin in iron homeostasis and describe factors and diseases that affect its expression. We also describe new studies which further characterize the structure and expression of a novel form of ferritin heavy $(H)$ chain mRNA that was identified in brain and discuss possible implications of these findings. Human fetal and adult brain cDNA libraries previously were screened with cDNA for well-characterized liver ferritin $\mathbf{H}$. In addition to 'liver-like' brain ferritin $\mathbf{H}$ cDNA, novel ferritin $H$ cDNAs with an additional 279 nucleotide sequence at the $\mathbf{3}^{\prime}$ untranslated region (UTR) were identified in both libraries (see refs. 1 and 2; Dhar, M., Chauthaiwale, V., and Joshi, J. G., Gene, 1993, 126, 275 and Dhar, M., and Joshi, J. G., J. Neurochem., 1993, 61, 2140). However, relative to liver ferritin H cDNA, these novel cDNAs were incomplete at their 5'ends [see ref. 3; Joshi, J. G., Fleming, J. T., Dhar, M. S., and Chauthaiwale, V., J. Neurol Sci., 1995, 134, (Suppl.), 52]. In the present paper, by sequencing of cDNAs using reverse transcriptase polymerase chain reaction, we show that the 279 nt $3^{\prime}$ UTR sequence, a coding sequence identical to that in human liver ferritin $\mathbf{H}$, and a full-length $5^{\prime}$ UTR that includes one mRNA regulatory iron-response element sequence, co-exist in at least one species of ferritin $H$ transcript in six normal human adult and six late-onset, sporadic Alzheimer disease (AD) brains. This sequence is the same in the normal and AD brains. Dot-blot analysis of poly A+ RNAs from different human tissues indicates that relative to the coding sequence of ferritin $H$, expression of the 279 nt $3^{\prime} U T R$ sequence varies among different tissues, is highest in the adult brain, and is very low in fetal brain. In normal adult hippocampus, ferritin H RNA with the novel 279 nt sequence localizes strongly to small non-neuronal cells, capillary endothelial cells, and to selected populations of neurons (granule cells of the dentate gyrus). Significant homology was observed between a region in the $279 \mathrm{nt}$ $3^{\prime}$ UTR segment of ferritin H RNA and the 3'UTR of cyclooxygenase- 2 mRNA (an inducible iron-containing enzyme involved in prostaglandin synthesis). Possible functions for ferritin $H$ protein derived from the novel message and for the elongated $3^{\prime}$ UTR and $5^{\prime}$ UTR are discussed.

Keywords: Human ferritin heavy chain; brain; cDNA sequence; Alzheimer's disease; iron metabolism; iron response element; 3'untranslated region; 5'untranslated region; cyclooxygenase-2; RNA secondary structure

\section{Introduction}

\section{Pathways involved in iron homeostasis}

Iron is not only a cofactor of many heme and non-heme enzymes, but it also is an essential participant in many metabolic processes including DNA, RNA, protein synthesis, the formation of myelins and development of neuronal dendritic trees. ${ }^{4}$ Because free iron will catalyze the formation of free radicals which oxidize nucleic acids, protein, and lipid, the metabolism of iron is highly regulated by complexing to specific transport and storage proteins. A number of different pathways involved in iron uptake by cells have been described; which pathways are used in a cell depends upon the cell type and the availability and need for iron. The pathway that has been most studied involves complexing of the iron transporting protein, transferrin, to the transferrin receptor, and internalization of the complex through receptor-mediated endocytosis. ${ }^{5-9}$ In this process, iron is liberated from the transferrin in the acidic endosome environment, transferrin is released into the extracellular fluid, and its receptor is recycled back to the plasma membrane. Immature erythroid cells are the most active in this function. The iron that is freed may be utilized in metabolic processes, sequestered and stored by ferritin, or transported through the cell. Transferrin also may be internalized by a transferrin-receptor independent system. Investigations using reticulocytes have demonstrated that the transferrin-transferrin receptor process disappears as they mature, and that uptake of ferrous iron is associated with $\mathrm{Na}^{+}$transport across the cell membrane. ${ }^{8}$ The uptake of iron from transferrin by isolated rat hepatocytes varies in parallel with plasma membrane $\mathrm{NADH}$ : ferricyanide oxidoreductase activity and is $\mathrm{Ca}^{2+}$ ion dependent. ${ }^{10}$ In intestinal cells, iron uptake proceeds exclusively via integrin and a cytosolic protein called mobilferritin. ${ }^{11}$ This latter pathway previously was demonstrated in reticulocytes and has been found to be a minor pathway in all nucleated cells studied to date. ${ }^{12}$ The presence of transferrin receptors on the luminal plasma membranes of the vascular endothelial cells, which constitute the blood-brain barrier, suggests that these participate in the transport of iron into the brain. Recent studies with rodent brain support a model in which the bulk of iron which enters brain via the binding of transferrin to tranferrin receptors exits with the bulk outflow of cerebrospinal fluid (CSF) through arachnoid villi and other channels. ${ }^{13}$ However, in a cell culture model of the blood-brain barrier consisting of a co-culture of bovine brain capillary endothelial cells and astrocytes, the majority of iron-loaded transferrin crossed the endothelial cells bound to transferrin, suggesting by-pass of the lysosomal compartment. ${ }^{14,15}$ Because

Presented at The Sixth Nordic Symposium on Trace Elements in Human Health and Disease, Roskilde, Denmark, June 29-July 3, 1997. 
the iron-binding protein p97 (also known as melanotransferrin) localizes to blood vessel walls in normal adult brains, p97 also has been implicated in transferring iron through the blood-brain barrier. ${ }^{16}$ It currently is believed that transferrin-bound iron can be used by all types of cells in all tissues in amounts that depend upon their complement of transferrin receptors. Although iron is transported in blood mainly bound to transferrin, in abnormal conditions other iron-containing compounds may become important. These include ferritin, hemopexin-heme, haptoglobin-hemoglobin, and non-specific non-transferrin-bound iron. ${ }^{8}$ In contrast to transferrin which is a high affinity, low capacity protein (two atoms of iron per molecule), ferritin is a lower affinity, higher capacity protein (maximum of 4500 iron atoms per molecule). In higher organisms iron bound to transferrin and stored in ferritin account for more than $90 \%$ of the total non-heme iron. ${ }^{17}$

\section{Ferritin structure and expression}

Ferritin $\left(M_{\mathrm{r}} 500 \mathrm{kDa}\right)$ is composed of 24 subunits consisting of variable numbers of $21 \mathrm{kDa}$ heavy $(\mathrm{H})$ chains and $19 \mathrm{kDa}$ light (L) chains which form a hollow protein shell.,3,17 The $\mathrm{H}$ and $\mathrm{L}$ chains are found associated in various ratios, giving rise to a wide range of isoforms depending on the physiological conditions and the type of tissue. ${ }^{18} \mathrm{H}$-chain rich ferritin accumulates and releases iron faster than L-chain rich ferritin does and predominates in cells and tissues which have a high level of oxidative respiration. The $\mathrm{L}$ subunit predominates in cells and tissues that store iron. The mechanisms by which iron is loaded into the ferritin shell is not well understood, but involves the conversion of toxic $\mathrm{Fe}^{2+}$ ions to the benign $\mathrm{Fe}^{3+}$ form. ${ }^{17}$ Factors that release iron from the ferritin shell (e.g., bursts of free radicals, high levels of ascorbic acid, or an acidic environment), result in the conversion of $\mathrm{Fe}^{3+}$ to catalytic $\mathrm{Fe}^{2+}$ which upon their release generate huge numbers of free radicals. Thus ferritin can be life-supporting or death-promoting, depending on the circumstances.

Changes in transcription/accumulation of ferritin messenger ribonucleic acid (mRNA) accompany cell differentiation in development as cells establish the pattern of iron metabolism and storage that matches their specialized features. ${ }^{19}$ Ferritin gene expression varies over 1000 -fold at different stages of development. ${ }^{20}$ Fetal brain has very little iron or ferritin, whereas adult brain contains large quantities of both. As much as a third of non-heme iron in adult brain is stored in this protein. ${ }^{3,21}$ Ferritin is approximately 10 times more abundant than transferrin throughout the brain, and it is evenly distributed as is iron, between gray and white matter. There is more ferritin $\mathrm{H}$ chain than $\mathrm{L}$ chain in the adult brain. ${ }^{18}$ Furthermore, HPLC analysis has revealed four distinct molecular species of brain ferritin $\mathrm{H}$ but only one major species of ferritin L chain. ${ }^{3}$ These observations collectively demonstrate the importance of ferritin $\mathrm{H}$ in the central nervous system.

\section{Factors regulating ferritin expression}

Two aspects of the regulation of ferritin expression are unusual. First, initiation of translation is remarkably efficient. Second, the intracellular iron concentration is a major regulator of the biosynthesis and accumulation of ferritin and certain other proteins involved in iron metabolism. ${ }^{19}$ This regulation is mostly exerted post-transcriptionally by specific mRNAprotein interactions between iron-regulatory proteins and a highly conserved 28 nucleotide (nt) sequence termed the 'ironresponsive element' or IRE ${ }^{20-22}$ contained in the $5^{\prime}$ untranslated region (UTR) of ferritin H- and L-subunit mRNAs. 3,17,23 IREs are also found in some mitochondrial enzymes [5-aminolevulinate synthase, ${ }^{24}$ mitochondrial aconitase, ${ }^{25}$ and succinate dehydrogenase (Drosophila $)^{26}$ ] as well as in transferrin ${ }^{27}$ and amyloid precursor protein. ${ }^{28}$ Several IRE repeats are present in the $3^{\prime}$ UTR of transferrin receptor mRNA. ${ }^{29}$ Two specific proteins, IRP1 and IRP2, which bind to IRE sequences have been isolated from rodent and human tissues or cells. ${ }^{30-32}$ Binding of these proteins to IREs in the $5^{\prime}$ UTR repress translation whereas binding to IREs in the $3^{\prime}$ UTR enhance message stability (by blocking the recognition site for the transcript's degradation apparatus) and enhance translation. ${ }^{7}$ The finding of IREs in mitochondrial enzymes indicates that there is a regulatory link between energy and iron metabolism and suggests biological functions for the IRE regulatory system in addition to iron homeostasis. The IRPs also bind to IRErelated structures in distinct sets of RNA target sequences, possibly extending their function beyond regulation of iron homeostasis. ${ }^{32}$

With the discovery of nitric oxide (NO), its role in host defense and its interactions with a number of different ironcontaining proteins, studies currently are beginning to unravel the connection between iron metabolism and NO. 9 Cells producing excess NO presently include endothelial cells, hematopoietic cells, hepatocytes, smooth muscle cells, chondrocytes and macrophages. Under inflammatory conditions, bacterial endotoxin and the inflammatory cytokines IL-1 $\beta$, IL6 , TNF- $\alpha$ and INF- $\gamma$ induce the transcription of nitric oxide synthase isoform-2 (NOS-2). (Inflammation is the induction of processes by tissue injury that promote healing.) NOS-2 catalyzes the formation of $\mathrm{NO}$ and citrulline from arginine. There is evidence that NO enhances the binding of IRP1 to IREs in ferritin and transferrin receptor mRNAs independently of the iron level. Another specific motif in the 5'UTR of ferritin mRNAs common also to certain other proteins, but distinct from the IRE, responds to IL- $1 \beta$ by derepression of $\mathrm{H}$-ferritin translation. ${ }^{33}$ One model predicts that in inflammation NO will induce a net increase in surface transferrin receptor expression and an increase in ferritin expression. ${ }^{9}$ Some inflammatory cytokines also induce ferritin $\mathrm{H}$ transcription through the activation of transcription factors AP1 and NF-KB. ${ }^{9}$

Other signals that induce changes in ferritin gene expression in mammalian cells include hormones (thyroid hormone, ${ }^{34}$ thyrotropin, ${ }^{35}$ insulin, ${ }^{36}$ progesterone, ${ }^{37}$ ) phagocytosis and/or inducing agents, ${ }^{38}$ tissue injury, ${ }^{39}$ heat shock, 40 ischemiareperfusion, ${ }^{41,42}$ hypoxia, ${ }^{43}$ differentiation ${ }^{44}$ and virus infection. 45

\section{Distribution of iron and iron-binding proteins in the central nervous system}

Localizing iron, ferritin and other major iron-binding proteins in brain tissue at the regional and cellular level is fundamental for understanding how iron gains entry into the brain and iron homeostasis in this organ. High levels of stainable non-heme iron have been reported in the extra-pyramidal system within the globus pallidus, substantia nigra zona reticulata, red nucleus and myelinated fibres of the putamen. Moderate staining has been found in the forebrain, mid-brain and cerebellar structures within the striatum, thalamus, cortex and deep white matter, substantia nigra zona compacta and cerebellar cortex. ${ }^{46}$ The brain-stem and spinal cord show low intensity staining. The levels of transferrin, transferrin receptor and non-heme iron in brain cells are not well correlated. ${ }^{4}$

In the brain, transferrin is found primarily in oligodendrocytes. These cells are important for myelin synthesis; they also are the predominant iron-containing cells in brain. Message for transferrin has been detected in the choroid plexus as well as in oligodendrocytes. Transferrin receptor is present on the surface of every cell requiring iron; it is abundantly expressed on blood vessels, large neurons in the cortex, striatum and hippocampus, and it also is present on oligodendrocytes and astrocytes. 48,49 Ferritin and iron are present in microglial cells (including 
perivascular microglia ${ }^{50}$ ) in all brain regions, but especially in the hippocampus. Immunostaining for ferritin also has been observed around the third ventricle where ferritin and iron are found in tanacytes. Some neurons immunostain specifically for ferritin $\mathrm{H}$ protein. Oligodendrocytes immunostain only for ferritin $\mathrm{H}$ early in development. ${ }^{48,49,51}$

\section{Aberrations of iron metabolism in ageing and in neurodegenerative diseases}

Characterizing the effects of ageing and of certain neurodegenerative diseases associated with accumulation of iron in the degenerating brain regions [e.g., Alzheimer's disease (AD), $3,4,28,52$ Parkinson's disease (PD), ${ }^{53}$ Huntington's disease, ${ }^{54}$ and Hallervorden-Spatz disease ${ }^{55}$ ] on brain iron distribution and on the expression of genes involved in iron homeostasis will contribute valuable information about factors regulating iron metabolism and help to clarify the aberrant processes that underlie, contribute to, or are associated with disease development. For example, the degree of iron deposition in the basal ganglia (especially the caudate and putamen) increases with age and especially in disorders involving the basal ganglia. ${ }^{4,56}$ With ageing, and in the basal ganglia disorders, microglia become more numerous and richer in iron and ferritin. ${ }^{4,57}$ In normal ageing, the levels of both ferritin $\mathrm{H}$ and ferritin $\mathrm{L}$ increase in parallel. In $\mathrm{AD}$ and $\mathrm{PD}$, however, the $\mathrm{H} / \mathrm{L}$ ratio of ferritin protein in vulnerable regions (frontal cortex in $\mathrm{AD}$; caudate and putamen in PD) is increased. ${ }^{51}$ In addition to aberrations of iron metabolism in the AD brain, aberrations in the central nervous system (CNS) and plasma also have been described. ${ }^{28,58}$ It has been suggested that trapping of non-heme iron by astroglial mitochondria may account for the accumulation of redox-active iron in degenerating brain regions. ${ }^{59}$ Experiments in rats indicate that increases in ferritin compensate for age-related increases in iron, and suggest that increased ferritin is cytoprotective and prevents the accumulation of protein carbonyl groups. ${ }^{60}$

\section{Ferritin and the acute phase response}

The body responds to tissue injury, infection and other types of traumatic stress by manifesting an acute phase response (APR) in an attempt to restore physiological homeostasis. The peripheral APR is mediated by inflammatory cytokines and nitric oxide. ${ }^{61}$ These up-regulate the synthesis of certain proteins (including ferritin) in the liver and down-regulate the synthesis of others (including transferrin). With respect to iron metabolism, the APR results in blockage of tissue iron release, decreased serum iron, transferrin, total-iron-binding capacity and increased serum ferritin. ${ }^{9}$ Analytical procedures currently are being developed to attempt to distinguish an APR from responses characteristic of iron overload.62,63 There is increasing evidence that an acute phase response also can be mounted in the CNS (possibly by the choroid plexus and macrophages) in response to cytokine release at sites of tissue injury in the brain. ${ }^{64}$ A chronic APR may eventually result in the anemia inflammation and in which is seen in certain chronic diseases. ${ }^{61}$

\section{Previous genetic studies of ferritin heavy chain in human fetal and adult brain}

The $\mathrm{H}$ and $\mathrm{L}$ subunits of ferritin are genetically and functionally distinct, and a study of them separately is essential for determining how iron is managed at the cellular and molecular level. Because of the central role that ferritin plays in iron homeostasis, and the observations which suggest that changes in ferritin $\mathrm{H}$ expression are particularly important in human development and in $\mathrm{AD}$, we have been studying ferritin $\mathrm{H}$ gene expression in brain. ${ }^{1-3,65-67}$ Northern blot analysis of polyA ${ }^{+}$ RNAs from human brain and liver with a human liver ferritin $\mathrm{H}$ chain probe previously revealed two different sizes of transcripts. A $1.4 \mathrm{~kb}$ RNA band was expressed predominantly in the brain whereas a $1.1 \mathrm{~kb}$ form was more abundant in liver.65 Subsequent screening of fetal and adult brain cDNA (DNA that is complementary to RNA) libraries yielded two types of human brain ferritin $\mathrm{H}$ cDNAs. They were sequenced using conventional techniques. One type of cDNA corresponded to the previously characterized $1.1 \mathrm{~kb}$ RNA from liver and lymphocytes. The second type contained the $3^{\prime}$ UTR sequence of liver ferritin $\mathrm{H}$ mRNA and an extra 279 nt segment at the $3^{\prime} \mathrm{UTR}$. This novel 279 nt 3'UTR corresponded to 'intron IV' of human liver ferritin $\mathrm{H}$ genomic sequence which was thought not to be transcribed into RNA, except that it had an apparent insert of 15 nt which corresponded to an ambiguous region of five nucleotides in the published genomic sequence (see Fig. 1). Utilization of alternative polyadenylation sites in the precursor mRNA was proposed to generate the ferritin $\mathrm{H}$ mRNA species which differed at their $3^{\prime}$ UTR ends. ${ }^{1,2}$ The $5^{\prime}$ UTR sequences of the larger mRNAs were incomplete, however. Fetal brain cDNA clones contained the elongated 3'UTR, the coding sequence of liver ferritin $\mathrm{H}$ mRNA, but only 130 of the $215 \mathrm{bp}$ of the liver ferritin 5'UTR. The IRE and the remainder of the $5^{\prime}$ UTR were absent. Adult brain cDNA clones contained the elongated 3'UTR, but the entire 5'UTR and the first 24 nucleotides (corresponding to 8 amino acids) of the coding sequence were absent. However, reverse transcriptase polymerase chain reaction (RT-PCR) analysis suggested that normal fetal and adult brain carried some ferritin $\mathrm{H}$ transcript with an elongated $3^{\prime} \mathrm{UTR}$ and a $5^{\prime}$ IRE like that of liver ferritin $\mathrm{H}^{3}$

\section{Objectives}

A long-term goal in our research has been to characterize aberrant processes which, if corrected, would lead to the rational development of treatments to slow down or prevent AD. Because aberrations of iron and ferritin metabolism have been described in $\mathrm{AD}$, and because an unusual form of message with an elongated $3^{\prime}$ UTR and truncated at the $5^{\prime}$ end was cloned from human brain cDNA libraries, it was considered important to determine if full-length ferritin H RNA with a normal 5'UTR existed in series of normal human adult and AD brains, and to determine if these had the same sequence. To gain new insight into the function of the novel $279 \mathrm{nt}$ segment in the ferritin $\mathrm{H}$ $3^{\prime} \mathrm{UTR}$, we also measured relative levels expression of the 279 nt 3'UTR sequence in different adult and fetal tissues and in different regions of the adult brain, and examined autopsy tissue from normal human hippocampus to determine which cell types expressed high levels of ferritin $\mathrm{H}$ with the novel $279 \mathrm{nt}$ sequence at the 3'UTR. Additionally, we applied RNA folding paradigms to study the conformation of ferritin $\mathrm{H}$ chain RNAs. Possible implications of our findings are discussed.

\section{Experimental procedures}

\section{Studies}

Four studies were carried out:

(a) Total RNA was extracted from hippocampal brain tissue of six normal human adults and six persons with autopsyverified $\mathrm{AD}$. After reverse transcription using a primer specific for the novel 279 nt sequence in the $3^{\prime} \mathrm{UTR}$ of ferritin H RNA, ferritin $\mathrm{H}$ cDNAs were produced by PCR amplification using appropriate oligonucleotide primers, purified by elution from agarose gel after electrophoresis, and sequenced.

(b) A human RNA Master blot was hybridized sequentially with probes for the ferritin $\mathrm{H}$ coding region, for the novel $279 \mathrm{nt}$ sequence at the $3^{\prime} \mathrm{UTR}$ of 'brain' ferritin H RNA, and ubiquitin as a control. 
(c) RT-PCR was carried out in situ on tissue sections from formalin-fixed paraffin-embedded normal adult human hippocampus to amplify and detect only ferritin H RNA possessing an elongated 3'UTR with the novel 279 nt sequence.

(d) Ferritin H RNA secondary structure predictions were determined using the Zuker Biofold program on BIONET and the University of Wisconsin's GCG software.

\section{Brain tissue}

Samples of adult human hippocampus from normal persons and from persons with late-onset, sporadic $\mathrm{AD}$ (i.e., $\mathrm{AD}$ manifesting after the age of 65 years with no previous family history of disease) for RNA extraction were obtained from Duke University Medical Center, Durham, NC, USA. Subject age varied from 59 to 93 years; autopsy was performed within 30-250 min. Sections of formalin-fixed, paraffin-embedded normal adult hippocampal tissue for the RNA localization study (cause of death, myocardial infarction; post-mortem interval, $3 \mathrm{~h}$ ) were provided by the Canadian Brain Bank, University of Toronto.

\section{Reagents}

Oligonucleotides P1 to P6 were obtained from Oligos, Guilford, CT, USA. Oligonucleotides P7 and P8 were obtained from Dalton Chemical, North York, Canada. Their designation, location, sequence and polarities are given in Fig. 1.

FN1 is a $0.718 \mathrm{~kb}$ 'liver-like' ferritin $\mathrm{H}$ brain cDNA probe isolated from an adult brain cDNA library. It contains the coding sequence common to all ferritin $\mathrm{H}$ cDNAs but lacks the $279 \mathrm{nt} 3^{\prime} \mathrm{UTR}$ sequence. It is cloned into the EcoRI site of the vector $\mathrm{pBSK}(+)$. FN30 is a $0.296 \mathrm{~kb}$ adult brain cDNA probe containing the $279 \mathrm{nt}$ sequence. It is cloned into the EcoRI/KpnI site of the vector pBSK(+). Purification of inserts from these probes has been described previously. ${ }^{67}$ Because FN30 has a poly $\mathrm{A}^{+}$tail at the $5^{\prime}$ end and a short sequence at the $3^{\prime}$ end which is complementary to the extreme $3^{\prime} \mathrm{UTR}$ of liver ferritin $\mathrm{H}$, a

$$
\begin{aligned}
& \stackrel{\text { CAGACGTTCTTCGCCGAGAGTCGTCGGGGTTRCCTGCTTCAACAGTGCTTGGACGGAZDC }}{\longrightarrow} \\
& \text { CGGCGCTCGTTCCCCACCCC̈GGCGGCCGCCCATAGCCAGCCCTCCETCÁCCTCTTCACC } 120
\end{aligned}
$$

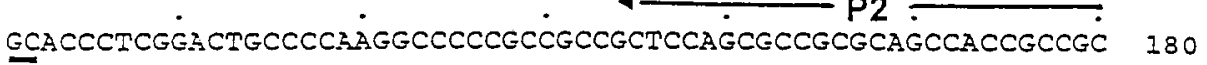

$$
\begin{aligned}
& \text { CGCCGCCGCCCTCTCCTTÁTTCGCCGCCATGACGACCGCGTCCACCTCGCAGGTGCGCCA } 240 \\
& M \quad T \quad T \quad A \quad S \quad T \quad S \text { Q } V \text { R } Q \\
& \text { GAACTACCACCAGGACTCAGAGGCCGCCATCAACCGCCAGATCAACCTGGAGCTCTACGC } 300
\end{aligned}
$$

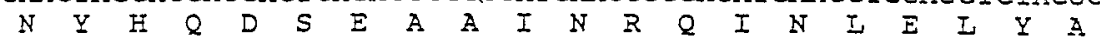

$$
\begin{aligned}
& \text { CTCCTACGTTTACCTGTCCATGTCTTACTACTTTGACCGCGATGATGTGGCTTTGAGGA } 360
\end{aligned}
$$

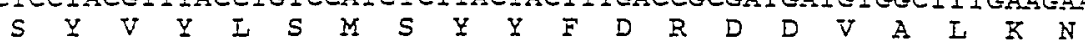

Fig. 1 Nucleotide sequence of one species of ferritin H cDNA from adult brain obtained by RT-PCR. The IRE and the extra 279 nt segment in the $3^{\prime}$ UTR are shown in the boxes. The nucleotide positions of primers P1-P8 are underlined. The arrows indicate the polarity. The $15 \mathrm{nt}$ region that is underscored by asterisks corresponds to a region of five unidentified nucleotides in the published ferritin $\mathrm{H}$ genomic sequence. ${ }^{81}$ The same sequence was obtained for six normal adult and six AD ferritin $\mathrm{H}$ cDNAs. 
PCR probe 'FN30 pcr' lacking these two 'problem' regions was constructed by PCR amplification using FN30 as template and appropriate primers $\mathrm{P} 1$ and P7, Fig. 2). FN30 ${ }_{\text {pcr }}$ was resolved by agarose gel electrophoresis and extracted after melting the agarose with Gene Clean II (BIO 101, La Jolla CA, USA). The ubiquitin cDNA probe was provided with the Master RNA Blot. GIBCO BRL T4 polynucleotide kinase and random priming labelling kits were from Life Technologies (Gaithersburg, MD, USA). Isotope was from ICN Pharmaceuticals, (Irvine, CA, USA) or Amersham, (Arlington Heights, IL, USA).

PCR reagents from Perkin Elmer (Norwalk, CT, USA) and Cyclist or Cyclist exo $^{-}$pfu sequencing kits from Stratagene (La Jolla, CA, USA) were used for sequencing of PCR fragments.

Electrophoresis reagents were from United States Biochemicals, Cleveland, OH, USA.

\section{Isolation of total RNA}

Total RNA from brain samples was isolated by the guanidine$\mathrm{HCl}$ method according to Sambrook et al., ${ }^{68}$ All samples were reverse-transcribed, PCR-amplified and sequenced as indicated below.

\section{Reverse transcription polymerase chain reaction}

A 30-mer oligonucleotide, (5'GAGAATTCCAGCCTTTAATGCCTTTTATTC $3^{\prime}$ ), which is identical to P1 and complementary to the $3^{\prime}$ end of 279 bp sequence but which contains an internal EcoRI site (underlined), was used to prime the reverse transcription (i.e., the first strand synthesis). The reaction mixture contained $10 \mu \mathrm{g}$ of heat-denatured total RNA from normal adult or AD brains, $2 \mathrm{~mm}$ of each dNTP, $5 \mathrm{~mm}$ $\mathrm{MgCl}_{2}, 50 \mathrm{~mm} \mathrm{KCl}, 50 \mathrm{pmol} \mathrm{P} 1,10 \mathrm{~mm}$ TRIS-HCl (pH 8.3), 50 $\mathrm{U}$ RNasin and $100 \mathrm{U}$ M-MulV reverse transcriptase in a final volume of $50 \mu \mathrm{l}$. After incubation at $37^{\circ} \mathrm{C}$ for $1 \mathrm{~h}$, the reaction was terminated by heating at $95{ }^{\circ} \mathrm{C}$ for $5 \mathrm{~min}$.

\section{A}

\begin{tabular}{|c|c|c|c|c|c|c|c|}
\hline 1 & 2 & 3 & 4 & 5 & 6 & 7 & 8 \\
\hline $\begin{array}{l}\text { whole } \\
\text { brain }\end{array}$ & amygdala & $\begin{array}{l}\text { caudate } \\
\text { nucleus }\end{array}$ & $\begin{array}{c}\text { cere- } \\
\text { bellum }\end{array}$ & $\begin{array}{c}\text { cerebral } \\
\text { cortex }\end{array}$ & $\begin{array}{c}\text { frontal } \\
\text { lobe }\end{array}$ & $\begin{array}{l}\text { hippo- } \\
\text { campus }\end{array}$ & \begin{tabular}{|} 
medulla \\
oblangata
\end{tabular} \\
\hline B $\mid \begin{array}{c}\text { occipital } \\
\text { lobe }\end{array}$ & putamen & $\begin{array}{c}\text { substantia } \\
\text { nigra }\end{array}$ & $\begin{array}{c}\text { temporal } \\
\text { lobe }\end{array}$ & thalamus & $\begin{array}{c}\text { sub. } \\
\text { thalamic } \\
\text { nucleus }\end{array}$ & $\begin{array}{l}\text { spinal } \\
\text { cord }\end{array}$ & \\
\hline heart & aona & $\begin{array}{l}\text { skeletal } \\
\text { muscle }\end{array}$ & colon & bladder & uterus & prostate & stomach \\
\hline Testis & ovary & pancreas & $\begin{array}{l}\text { pituitary } \\
\text { gland }\end{array}$ & \begin{tabular}{|c} 
adrenal \\
gland
\end{tabular} & $\begin{array}{l}\text { thyroid } \\
\text { gland }\end{array}$ & $\begin{array}{l}\text { salivary } \\
\text { gland }\end{array}$ & $\begin{array}{c}\text { mammary } \\
\text { gland }\end{array}$ \\
\hline kidney & liver & \begin{tabular}{|c} 
small \\
intestine
\end{tabular} & spleen & thymus & $\begin{array}{l}\text { peripheral } \\
\text { leukocre }\end{array}$ & $\begin{array}{c}\text { lymph } \\
\text { node }\end{array}$ & $\begin{array}{c}\text { bone } \\
\text { marrow }\end{array}$ \\
\hline F appendix & lung & trachea & placenta & & & & \\
\hline $\begin{array}{l}\text { tetal } \\
\text { brain }\end{array}$ & $\begin{array}{l}\text { tetal } \\
\text { heart }\end{array}$ & $\begin{array}{c}\text { fetal } \\
\text { kidney }\end{array}$ & $\begin{array}{l}\text { fetal } \\
\text { liver }\end{array}$ & $\begin{array}{l}\text { fetal } \\
\text { spleen }\end{array}$ & $\begin{array}{c}\text { fetal } \\
\text { thymus }\end{array}$ & $\begin{array}{l}\text { fetal } \\
\text { lung }\end{array}$ & \\
\hline $\begin{array}{c}\text { yeast } \\
\text { 10tal RNA } \\
100 \mathrm{ng}\end{array}$ & $\begin{array}{l}\text { yeast } \\
\text { tRNA } \\
100 \cap g\end{array}$ & $\begin{array}{l}\text { E COl' } \\
\text { IRNA } \\
\text { IDO ng }\end{array}$ & $\begin{array}{l}E \text { coh } \\
\text { DNA } \\
100 \mathrm{ng}\end{array}$ & $\begin{array}{c}\text { Poly riA } \\
100 \mathrm{ng}\end{array}$ & $\begin{array}{c}\text { human } \\
C_{0} 11 \text { DNA } \\
100 \mathrm{ng}\end{array}$ & $\begin{array}{l}\text { human } \\
\text { DNA } \\
100 \mathrm{ng}\end{array}$ & $\begin{array}{l}\text { human } \\
\text { ONA } \\
500 \mathrm{ng}\end{array}$ \\
\hline
\end{tabular}

Two PCR reactions were then carried out on each sample using an aliquot of 2-5 $\mu \mathrm{l}$ of first strand mix, and 20 pmol each of P1 as the upstream primer and either P4 or P5 (Fig. 1) as the downstream primer, $1.5 \mathrm{~mm} \mathrm{MgCl} 2,200 \mu \mathrm{M}$ of each dNTP, 50 $\mathrm{mm} \mathrm{KCl}, 10 \mathrm{~mm}$ TRIS-HCl (pH 8.3) and $2 \mathrm{U}$ of Taq DNA polymerase in a final volume of $100 \mu$ l. PCR was performed in a Perkin Elmer Cetus thermal cycler at $95{ }^{\circ} \mathrm{C}$ for $1 \mathrm{~min}, 50{ }^{\circ} \mathrm{C}$ for $1 \mathrm{~min}, 72{ }^{\circ} \mathrm{C}$ for $2 \mathrm{~min}$ for 35 cycles followed by $10 \mathrm{~min}$ extension at $72{ }^{\circ} \mathrm{C}$.

\section{DNA sequencing}

PCR products from the two amplification reactions described above were resolved by electrophoresis on a $1.2 \%$ agarose gel, electroeluted, and directly sequenced using Cyclist or Cyclist $\mathrm{exo}^{-}$pfu DNA sequencing kits (Stratagene). Appropriate oligomers corresponding to the known fetal brain ferritin $\mathrm{H}$ cDNA $^{1}$ were used for sequencing.

\section{Human RNA master blots and hybridization protocols}

The Human RNA Master Blot (Clonetech, Palo Alto, CA, USA) is a positively charged nylon membrane to which poly $\mathrm{A}^{+} \mathrm{RNAs}$ from 50 human tissues have been immobilized in separate dots along with several controls. Master Blot hybridization provides a convenient method for obtaining information about the expression of a cloned gene of interest across a wide range of human tissues, for determining tissue or developmental-stage specificity of gene expression, and information about relative levels of mRNA abundance. The loading of poly $\mathrm{A}^{+} \mathrm{RNA}$ on each dot of the RNA master blots (which varies from 100-500 $\mathrm{ng}$ ) is normalized to eight different housekeeping genes so that the maximum dot-to-dot variation in the normalized signal from all eight housekeeping gene probes is less than $50 \%$ from the average level. DNA probes were labelled by random priming with $\left[{ }^{32} \mathrm{P}\right] \mathrm{dCTP}$. Oligonucleotides were $5^{\prime}$ end-labelled with
B

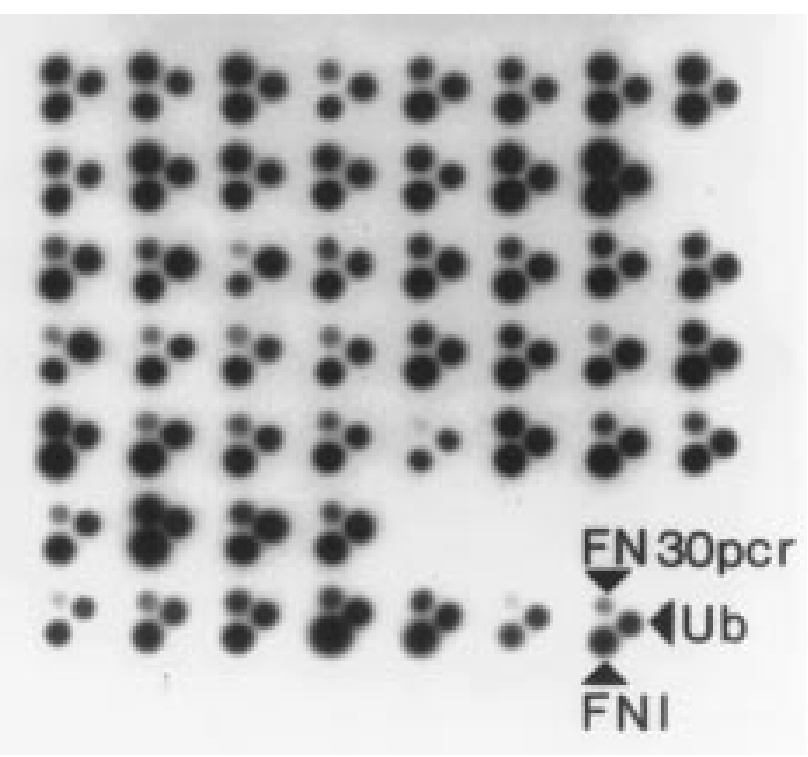

Fig. 2 Human RNA Master Blot Data. A, Diagram of the type and position of denatured poly A+ RNAs and controls dotted on the positively charged nylon membrane. Actual membrane size is $80 \times 120 \mathrm{~mm}$. B. Composite autoradiogram obtained by hybridizing one Master Blot with three different radiolabelled probes: FN1, a cDNA probe containing a portion of the open reading frame (ORF) common to all ferritin $\mathrm{H}$ cDNAs (bottom set of dots); FN30 stranded PCR probe corresponding to the novel 279 nt 3'UTR sequence of brain ferritin H chain cDNA (top set of dots); and, Ub, a ubiquitin cDNA probe (intermediate level of dots offset to the right). After each hybridization, an autoradiographic image of the blot was obtained. Autoradiograms from the three hybridizations were superimposed to yield the composite image. Exposure times were $2 \mathrm{~d}, 30 \mathrm{~d}$ and $2 \mathrm{~h}$, respectively, for FN1, FN30 and Ub. Thus when the FN1 and FN30 ${ }_{\text {pcr }}$ dots are of equal intensity, there is approximately 15 -fold more ferritin ORF sequence than the 279 nt segment. 
[32P]ATP and T4 polynucleotide kinase. Procedures used in the Human RNA Master Blot User Manual were followed for radiolabelling of probes, hybridization, and for washing the blots. Probe binding was visualized by autoradiography using X-OMAT AR X-ray film (Eastman Kodak, Rochester, NY, USA) and image intensifiers. Exposure times varied from $2 \mathrm{~h}$ to 1 month. Individual DNA probes were stripped from the Master Blot by boiling the membrane for 5-10 min in $250 \mathrm{ml}$ of $0.5 \%$ SDS followed by cooling for $10 \mathrm{~min}$, a procedure that was repeated four times altogether. After stripping, damp blots were stored between MM no. 3 filter paper moistened in 2X SSC in plastic wrap at $-70{ }^{\circ} \mathrm{C}$ until needed. Relative intensities of signals obtained with different probes were scored by inspection of composite autoradiographs.

\section{Tissue In Situ reverse transcriptase polymerase chain reaction (RT-PCR) analysis}

The exquisitely sensitive and specific new technique of in situ RT-PCR analysis enables specific RNA (or DNA) sequences to be amplified and readily detected in single cells on sections of formalin-fixed, paraffin-embedded autopsy tissue. This procedure was applied to sections of normal adult human hippocampus in order to visualize the relative levels of only ferritin $\mathrm{H}$ RNA which contains the novel 279 nt segment in the 3'UTR (as opposed to total ferritin H RNA levels or any RNA with the 279 nt segment) in different cell types. The protocol of Nuovo ${ }^{69}$ was followed with the exception that the PCR reaction was carried out with unlabelled nucleotides and PCR product was detected by conventional in situ hybridization with a $\left[{ }^{3} \mathrm{H}\right]$-labelled 'sense' oligonucleotide corresponding to a sequence in the amplified DNA which does not overlap with sequences of the oligos used to prime the reaction. Briefly, after de-waxing, tissue sections were treated with proteinase $\mathrm{K}$ (to permeabilize the tissue) and then with RNase-free DNase (to remove genomic and mitochondrial DNA). Sections treated with proteinase $\mathrm{K}$, RNase and DNase were used as the negative control. Reverse transcription of RNA into cDNA then was carried out in situ using random hexamers as primers. To amplify the sequence of interest in this cDNA, PCR was then carried out in situ using oligonucleotides P1 and P4 (Fig. 1) as described above. To detect specific PCR product, sections then were hybridized with oligonucleotide P7 (Fig. 1) which was 'tailed' at the $3^{\prime}$ end with $\left[{ }^{3} \mathrm{H}\right] \mathrm{dCTP}$ and dATP using terminal deoxynucleotidyl transferase. Enzyme reactions, PCR amplifications, and hybridizations were done using a Coy TempCycler II Slide Cycler, Diamed Lab Supplies, Mississauga, Ontario, Canada. After washing, slides were dipped in autoradiographic emulsion and refrigerated in a light-tight container at $4{ }^{\circ} \mathrm{C}$. After developing and fixing, and staining with hematoxylin-eosin, sites to which labelled oligonucleotide has bound are revealed as black grains of silver upon high magnification. ${ }^{70}$

\section{Results}

\section{(a) Sequencing of RT-PCR products}

Reverse transcription of all total RNA preparations was primed with oligonucleotide P1 corresponding to the extreme $3^{\prime}$ end of the 279 nt sequence; all PCR amplifications were done using this first strand mix. The sequence of adult ferritin $\mathrm{H}$ cDNA obtained from analysis of PCR products using primers 1 and 4, or 1 and 5 was found to be identical in the six normal adult brains and six late-onset AD brains. The full-length cDNA sequence is given in Fig. 1. This has a $5^{\prime} U T R$ that is identical to that of liver ferritin $\mathrm{H} \mathrm{cDNA}$ and includes an IRE; the coding sequence is identical to that reported for liver and fetal brain ferritin H cDNA. This full-length cDNA also has an elongated $3^{\prime}$ UTR containing the novel $279 \mathrm{nt}$ segment which is identical to that described previously. To further confirm the $5^{\prime} \mathrm{UTR}$ of 279 nt containing transcripts, the first strand mix obtained with $\mathrm{P} 1$ as primer was PCR-amplified using the previously reported transcription start point (tsp) as downstream primer (P6 in Fig. 1) along with P1 as the upstream primer, and the PCR fragment was sequenced at the $5^{\prime} \mathrm{UTR}$. The results were as expected. The PCR fragment sizes and sequence analysis rule out the possibility of an amplification of a contaminating genomic DNA in the RNA preparations because the sequence lacks introns. In summary, these data show that at least one species of ferritin $\mathrm{H}$ cDNA in the present series of $\mathrm{AD}$ and normal adult brains differs from liver-like ferritin $\mathrm{H}$ cDNA only by the presence of an extra 279 nt segment in the $3^{\prime}$ UTR. Second, they also show that the apparent $15 \mathrm{nt}$ insert in the 3'UTR (denoted by asterisks in Fig. 1) likely is not an allelic variation since this was present in RNAs from all of the subjects. Finally, the finding that all of the normals and AD cases had the same ferritin $\mathrm{H}$ cDNA sequence indicates that serious splicing defects which prevent formation of full length ferritin $\mathrm{H}$ message, insertions, deletions, or point mutations in the coding sequence, are not associated with the present series of AD cases. These studies do not exclude the possibility that mutations in ferritin $\mathrm{H}$ are associated with or linked to $\mathrm{AD}$ generally, or to different sub-types of AD, particularly the earlyonset forms.

\section{(b) Master blot analysis}

Inspection of the dot blots (Fig. 2) shows that the pattern of expression of the $297 \mathrm{nt}$ sequence relative to expression of the ferritin $\mathrm{H}$ coding sequence is tissue specific and highest in adult brain. Within the 14 adult brain regions examined, levels were highest in amygdala, caudate nucleus, putamen, substantia nigra and spinal cord, and lowest in cerebellum, indicating regionspecific expression within the brain. High expression also was apparent in adult kidney, lung, and peripheral leukocytes. Moderate expression was apparent in heart, aorta, colon, bladder, prostate, stomach, adrenal gland, thyroid gland, mammary gland, and trachea. Low relative levels were apparent in adult skeletal muscle, testis, ovary, pancreas, pituitary gland, salivary gland, liver, small intestine, spleen, thymus, and appendix, and in fetal brain, heart, lung and thymus. The data shown in Fig. 2 were confirmed by independent hybridization experiments of the same blot. Furthermore, hybridization with P8, a 50-mer oligonucleotide corresponding to positions 936-986 (in the 279 nt 3'UTR segment) yielded a pattern that was indistinguishable from that obtained using the $\mathrm{FN} 30_{\mathrm{pcr}}$ probe, although signals were weaker (data not shown). The low relative level of the $279 \mathrm{nt}$ sequence in fetal as compared to adult brain is indicative of developmental regulation in this organ, and the great importance of this sequence in adult brain.

The dot blot analysis described in this paper complements previous northern blot data which showed that $1.4 \mathrm{~kb}$ ferritin $\mathrm{H}$ polyA $^{+}$RNA is much more abundant in brain than in liver in which the predominant species is $1.1 \mathrm{~kb} .{ }^{65}$

\section{(c) Tissue In Situ RT PCR analysis}

The photographs in Figs. 3A, B and C show that in normal adult hippocampus, the novel 279 nt $3^{\prime}$ UTR sequence in ferritin $\mathrm{H}$ localizes strongly to non-neuronal (astroglial) cells, capillary endothelial cells, and to selected populations of neurons (the granule cells of the dentate gyrus). Signals in the negative control section (pre-treated with RNase before RT-PCR) were substantially less than in the test reactions (Fig. 3D).

\section{(d) RNA folding}

Predicted secondary structures for ferritin H RNAs showed a high degree of intra-chain base-pairing (Fig. 4). Interestingly, 
residues 999 to 1120 (located in the novel 279 nt 3'UTR of FTH) formed three 'stem-loops' (denoted L1, L2 and L3) which were a constant feature of structures predicted by both the Zuker and GCG software programs over a wide energy range. A Blast search $^{71}$ revealed homology between positions 1013 and 1095 of this stem-loop region, and a region in the $3^{\prime} \mathrm{UTR}$ of human endoperoxide synthase type II-cyclooxygenase-2 (COX-2) (Fig. 5). (Human endoperoxide synthase type II appears to be related to COX-2 by alternative splicing; these enzymes are rate-limiting in the synthesis of prostaglandins which are important mediators of inflammation. ${ }^{72,73}$ These observations suggest a functional importance for positions 1013-1095 of the novel 279 nt 3'UTR segment of ferritin H RNA which has been evolutionarily conserved.

Although homology to a small region of the $279 \mathrm{nt}$ sequence in the 3'UTR of ferritin H cDNA has been found in the 3'UTR of COX-2 mRNA, the 279 nt sequence, in toto, seems to be uniquely associated with the functional ferritin $\mathrm{H}$ gene and mRNA. Using PCR analysis, we previously showed that the cDNA sequence extending from within a consensus sequence in the coding region to the end of the elongated 3'UTR mapped to the same locus on human chromosome 11 as the functional gene for liver ferritin H.67 Application of the same approach has shown that no human chromosomes other than 11 carry the 279 nt $3^{\prime}$ UTR sequence in entirety. ${ }^{74}$ These observations indicate that the entire $279 \mathrm{nt}$ sequence is not likely to be present in any other human gene, including the many ferritin $\mathrm{H}$ pseudogenes that exist on any human chromosomes other than 11, and that it likely is not present in the gene for liver ferritin L or its pseudogenes. Screening of brain cDNA libraries with a probe for liver ferritin $\mathrm{L}$ also did not reveal any clones of novel size. ${ }^{3}$

Our finding of small sequences homologous to the $279 \mathrm{nt}$ segment in regions of the genome distinct from the functional ferritin $\mathrm{H}$ gene raises the possibility that a portion of the signal obtained with the $279 \mathrm{nt}$ probe originates from non-ferritin $\mathrm{H}$ RNA. There is no evidence from northern blotting that this is the case for adult tissue. In fetal brain, however, a probe containing the $279 \mathrm{nt}$ segment hybridized not only to a $1.4 \mathrm{~kb}$ ferritin $\mathrm{H}$ band, but also to a $1.55 \mathrm{~kb}$ band which did not hybridize to the coding sequence of ferritin $\mathrm{H}$. The origin of this signal is not clear. If it is COX-2 mRNA, the size of the cross-hybridizing mRNA species in fetal brain $(1.55 \mathrm{~kb})$ is distinct from published sizes of 2.8 and $4.6-4.8 \mathrm{~kb}$ for COX-2 mRNA. ${ }^{72,73}$

\section{Discussion}

Our observations that the level of the normal $279 \mathrm{nt}$ segment of ferritin H RNA (relative to the level of the ferritin $\mathrm{H}$ coding sequence) is highest in adult human brain, and that within this organ the levels of ferritin H message with the elongated 3'UTR are high in vascular endothelium and astroglial cells of the hippocampus, suggest that ferritin $\mathrm{H}$ may be particularly important in the vasculoendothelial-astroglial compartment.

Attempts to interpret these findings must be considered speculative. First, as indicated in background, our understanding of mechanisms of iron transport and homeostasis in the brain are in their relative infancy. No consensus has yet been reached about how iron is moved through the blood-brain barrier. ${ }^{13,14}$ Furthermore, knowledge that we do have has

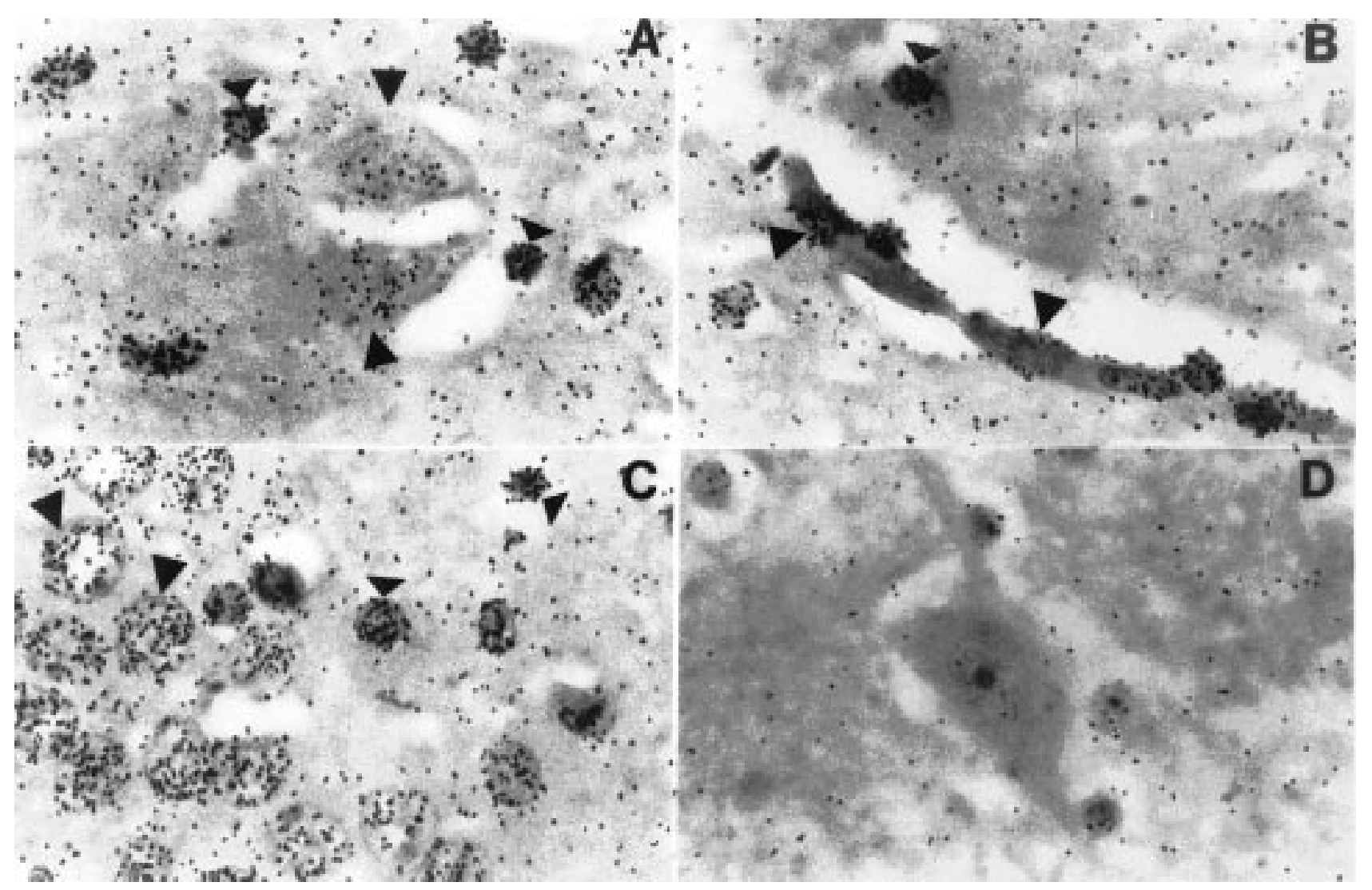

Fig. 3 Localization of ferritin $\mathrm{H}$ chain RNA containing the 279 nt sequence in hippocampal tissue of a normal adult. The procedure of tissue in situ RT-PCR analysis was used to identify cells containing this RNA as indicated in the text. The number of grains associated with a cell is approximately proportional to the number of molecules which hybridize to the radioactively-labelled probe. ${ }^{70}$ Details of hybridization with radioactive probes are given in ref. 70 . A, Large arrows denote large neurons; small arrows, astroglial cells. B, Large arrows denote capillary endothelial cells; small arrows, astroglial cells. C, Large arrows denote granule cells of the dentate gyrus; small arrows, astroglial cells. D, Negative control. Tissue section was treated with RNase before application of tissue in situ RT-PCR. 
largely been gleaned from animal experiments. Second, it is not known if the novel form of ferritin H RNA that we have been studying in human tissue exists in other animal species. Finally, it has not yet been shown that the translation of ferritin $\mathrm{H}$ protein is supported by message with the elongated $3^{\prime}$ UTR. Previous work has shown that in order to prepare for a rapid increase in ferritin in response to a rise in cellular iron, a large number of dormant ferritin $\mathrm{H}$ mRNAs are accumulated in cytoplasm. ${ }^{75}$

Assuming that ferritin $\mathrm{H}$ protein is produced from message with the $279 \mathrm{nt}$ segment in the $3^{\prime} \mathrm{UTR}$, fundamental questions to be resolved are whether this is most important in protection against oxidative stress, cellular metabolic processes, movement of iron into, through or from cells, iron storage, inflammatory processes, basal expression, induction, and/or tissue specific expression, and what the specific function of the novel 279 nt 3'UTR segment might be.

There is insufficient knowledge for one process to be highlighted over another. However, the high lipid content, high rate of oxidative metabolism and high iron content collectively make the brain the organ most vulnerable to oxidative stress. ${ }^{76}$ (In the presence of $\mathrm{Fe}^{2+}$, hydroxyl radicals are generated from $\mathrm{H}_{2} \mathrm{O}_{2}$; these initiate a free radical cascade.) Because levels of the 279 nt 3'UTR segment are expressed most highly in brain, a cytoprotective function for the elongated ferritin $\mathrm{H}$ message is implicated. Special cytoprotection might be particularly important in capillary endothelium because this constitutes the blood-brain barrier. ${ }^{77}$ Added cytoprotection would also be important in phagocytic (microglial) cells since these produce superoxide anions and ingest iron in tissue injury. ${ }^{38}$ Not clear, however, is why ferritin $\mathrm{H}$ produced by 'liver-like' ferritin $\mathrm{H}$ message which lacks the 279 nt segment in the $3^{\prime}$ UTR would not suffice.

The steady state level of a message is governed by factors regulating its translation, transcription and degradation. The cytoplasmic regulation of translation by $3^{\prime}$ UTRs is of increasing interest because these not only can affect message stability but also translation and message localization. ${ }^{78}$ In vitro translation studies of bullfrog ferritin $\mathrm{H}$ message that long-range interaction occurs between the 5'UTR and the 3'UTR, since translation could not be repressed by reticulocyte extract (presumably by IRP) when the first 70 residues of the $3^{\prime}$ UTR were missing. ${ }^{79}$ The identification of one species of ferritin $\mathrm{H}$ RNA which carries an intact 5'UTR including the IRE, and the IL-1 $\beta$ responsive element and an elongated $3^{\prime}$ UTR, ${ }^{33}$ will enable effects of new long-range interactions between the $5^{\prime}$ and $3^{\prime}$ UTRs on in vitro translation to be studied in the presence/ absence of modulatory factors. The findings that the cytoplasmic iron responsive protein has two forms which are differentially regulated by $\mathrm{NO}$ and which may each regulate unique mRNA targets, ${ }^{32}$ and that IL- $1 \beta$ enhances ferritin translation by interaction with a $5^{\prime}$ regulatory region that is independent of the IRE, ${ }^{33}$ open exciting new avenues for research. Studies of the regulation of translation also should include the contribution of the poly $\mathrm{A}^{+}$tail. Although this

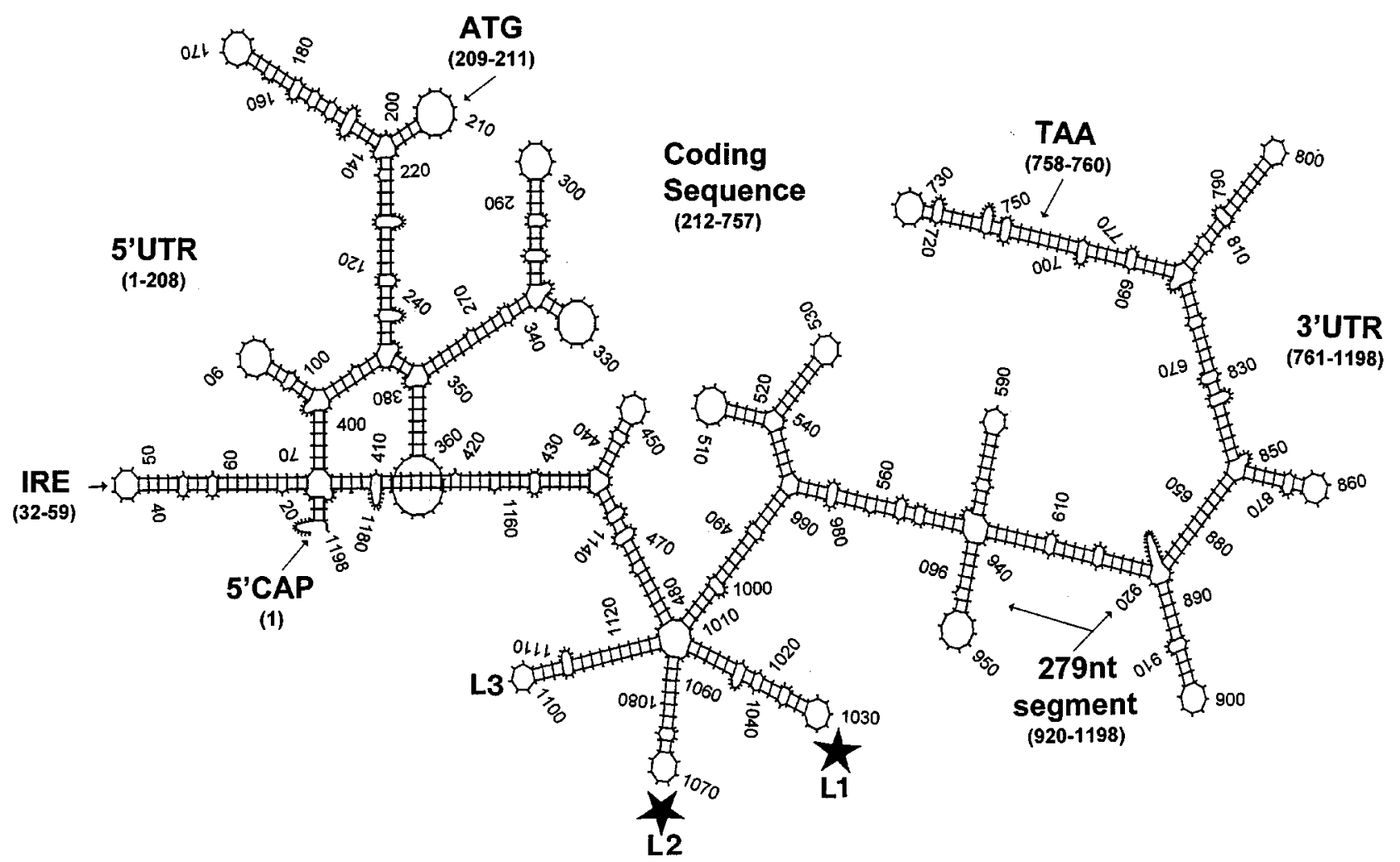

Fig. 4 Predicted secondary structure of full-length ferritin H chain mRNA using the GCG program (energy level, -318.1). Position numbers (in brackets) correspond to those in Fig. 2. The beginning of the ferritin H mRNA molecule (5'CAP), the IRE element (IRE), the codon (ATG) which would initiate translation in this sequence, the codon (UAA) which would terminate translation in this sequence, and the beginning of the 279 nt 3 'UTR segment are noted on the diagram. The three stem-loops (L1, L2 and L3) are a constant feature of structures predicted by the Zuker and GCG programs over a wide range of energy levels. The sequence of stem-loops L1 and/or L2 are conserved in mRNAs of human COX-2.

\section{A 1013 AATCAAAAAGAAACGAGTATTTGTATTTATTAAACTCATTAGTTTGGGCAGTATACTAAGGTGTGGCTGTCTTGGATTCAGAT 1095

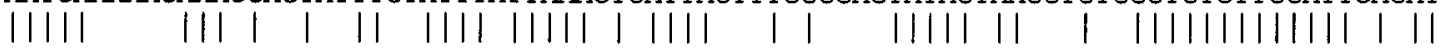 \\ B 2476 AATCACCTGTAAAAGCTTGATTTGATTTCTTAAAGTTATTAAACTTGTACATATACCAAAAAGAAGCTGTCTTGGATTTAAAT 2558}

Fig. 5 Homology between the 279 nt region in the $3^{\prime}$ UTR of human ferritin H RNA and the 3'UTR of human endoperoxide synthase type IIcyclooxygenase-2 (COX-2) mRNA. A, Nucleotide sequence of ferritin H cDNA. B, Nucleotide sequence of COX-2 mRNA. 
previously was thought to retard $3^{\prime}-5^{\prime}$ degradation by exoribonucleases, current evidence indicates that it has an important regulatory role. ${ }^{78}$

In contrast to our knowledge of factors regulating message translation, the mechanisms and trans-activating factors by which transcription is regulated either in terms of basal expression, induction or tissue-specific expression, are poorly understood. 'Liver-like' ferritin $\mathrm{H}$ message and the elongated 'brain' form appear to be derived from the same gene by differential polyadenylation. ${ }^{3}$ Identifying factors or conditions that result in the differential transcription of the two forms of ferritin $\mathrm{H}$ message will be of great importance for the field of brain iron homeostasis.

Although our work has shown that both normal adult and late onset, sporadic AD brains carry some full-length mature ferritin H RNA with an elongated $3^{\prime}$ UTR and a 5'UTR with an IRE, Northern blotting, primer extension analysis and RNase protection assays must be done to characterize and compare ferritin $\mathrm{H}$ mRNA heterogeneity in normal and AD brain tissues. ${ }^{68}$ Not established is whether the brain ferritin $\mathrm{H}$ cDNAs which are truncated at the $5^{\prime}$ end that we have isolated from brain cDNA libraries ${ }^{1-3}$ are functionally significant or represent prematurely-terminated reverse transcription products.

The reader is referred to other recent reviews for additional detail about the regulation of cellular iron metabolism in health, inflammation and chronic disease. $4,7,9,80$

In summary, our understanding of iron homeostasis in the human brain is in its infancy. Investigations into the function and significance of an elongated form of ferritin $\mathrm{H}$ message which carries a novel $279 \mathrm{nt}$ segment in the $3^{\prime} \mathrm{UTR}$, and which is expressed strongly in the vasculoendothelial-astroglial compartment in brain, are important directions of investigation.

The authors thank Bryan Alzheimer's Disease Research Center at Duke University Medical Center, Durham, NC 27710 for normal and AD brain samples, Dr. C. Bergeron and L. Weyer for sections of normal adult hippocampus, and S. Rainey for samples of FN1 and FN30 insert. Support for this research was provided, in part, by the Council for Tobacco Research, Physicians' Medical Education Research Fund, Knoxville, TN, the Queen Elizabeth Hospital Research Institute, Toronto, ON, Canada, the Scottish Charitable Rite Foundation of Canada, Surrey Place Centre, Toronto, ON, the University of Toronto Life Sciences Summer Student Program, the SEED Program, and the Government of Ontario Work-Study Program.

\section{References}

1 Dhar, M., Chauthaiwale, V., and Joshi, J. G., Gene, 1993, 126, 275.

2 Dhar, M., and Joshi, J. G., J. Neurochem., 1993, 61, 2140.

3 Joshi, J. G., Fleming, J. T., Dhar, M., and Chauthaiwale, V., J. Neurol. Sci., 1995, 134, (Suppl.), 52.

4 Gerlach, M., Ben-Shachar, D., Riederer, P., and Youdim, M. B. J. Neurochem., 1994, 63, 793.

5 Klausner, R. D., Renswoude, J. V., Ashweel, G., Kempt, C., Schechter, A. N., Dean, A., and Bridges, K. R., J. Biol. Chem., 1983, 258, 4715 .

6 Theil, E. C., J. Biol. Chem., 1990, 265, 4771.

7 Crichton, R. R., and Ward, R. J., Analyst, 1995, 120, 693

8 Morgan, E. H., J. Gastroenterol. Hepatol., 1996, 11, 1027.

9 Domachowske, J. B., Biochem. Mol. Med., 1997, 60, 1.

10 Thorstensen, K., and Romslo, I., J. Biol. Chem., 1988, 262, 8844.

11 Wolf, G., and Wessling-Resnick, M., Nutr. Rev., 1994, 52, 387.

12 Umbreit, J. N., Conrad, M. E., Berry, M. A., Moore, E. G., Latour, L. F., Tolliver, B. A., and Elkhalifa, M. Y., Br. J. Haematol., 1997, 96, 521 .
13 Bradbury, M. W., J. Neurochem., 1997, 69, 443.

14 Descamps, L., Dehouck, M. P., Torpier, G., and Cecchelli, R., Am. J. Physiol., 1996, 270, H1149.

15 Van Gelder, W., Cleton-Soeteman, M. I., Huijskes-Heins, M. I., van Run, P. R., and van Eijk, H. G., Brain Res., 1997, 746, 105.

16 Kennard, M. L., Richardson, D. R., Gabathuler, R., Ponka, P., and Jefferies, W. A., EMBO J., 1995, 14, 4178.

17 Beard, J. L., Dawson, H., and Pinero, D. J., Nutr. Rev., 1996, 54, 295.

18 Connor, J. R., Boeshore, K. L., Benkovic, S. A., and Menzies, S. L., J. Neurosci. Res., 1994, 37, 461.

19 Theil, E. C., Enzyme, 1990, 44, 68

20 Theil, E. C., in Hemoglobins in Development and Differentiation, ed. Stamatoyannopoulos, G., and Neinhuis, A., Liss, New York, 1981, pp. 423-431.

21 Joshi, J. G., Dhar, M., Clauberg, M., and Chauthaiwale, V., Environ. Health Perspect., 1994, 102, Suppl. 3, 207.

22 Rouault, T. A., Hentze, M. W., Haile, D. J., Harford, J. B., and Klausner, R. D., Proc. Natl. Acad. Sci. USA., 1989, 86, 5768.

23 Thorstensen, K., and Romslo, J., Biochem. J., 1990, 271, 1.

24 Melefors, O., Goossen, B., Johansson, H. E., Stripecke, R., Gray, N. K., and Hentze, M. W., J. Biol. Chem., 1993, 268, 5974.

25 Kim, H. Y., La Vaute, T., Iwai, K., Klausner, R. D., and Rouault, T. A., J. Biol. Chem., 1996, 271, 24226.

26 Gray, N. K., Pantopoulous, K., Dandekar, T., Ackrell, B. A., and Hentze, M. W., Proc. Nat. Acad. Sci. USA, 1996, 93, 4925.

27 Cox, L. A., Kennedy, M. C., and Adrian, G. S., Biochem. Biophys. Res. Commun., 1995, 212, 925.

28 Feldman, H., Kennard, M., Yamada, T., Adams, S., and Jefferies, W. Alzheimer's Disease: Biology, Diagnosis and Therapeutics, ed. Iqbal, K., Winblad, B., Nishimura, T., Takaeda, M, and Wisniewski, H. M., Wiley New York, 1997, pp. 189-196.

29 Mullner, E. W., Neupert, B., and Kuhn, L. C., Cell, 1989, 58, 373.

30 Guo, B., Yu, Y., and Leibold, E. A., J. Biol. Chem., 1994, 269, 24252 .

31 Hu, J., and Connor, J. R., J. Neurochem., 1996, 67, 838.

32 Henderson, B. R., Menotti, E., and Kuhn, L. C., J. Biol. Chem., 1996, 271, 4900.

33 Westmacott, D., Hawkes, J. E., Hill, R. P., Clarke, L. E., and Bloxham, D. P., Lymphokine Res., 1986, 5, S87.

34 Iwasa ,Y., Aida, K., Yokomori, N., Inoue, M., and Onaya, T., Biochem. Biophys. Res. Commun., 1990, 167, 1279.

35 Iwasa, Y., Aida, K., Yokomori, N., Inoue, M., and Onaya, T., Biochem. Int., 1990, 21, 473.

36 Yokomori, N., Iwasa, Y., Aida, K., Inoue, M., Tawata, M., and Onaya, T., Endocrinology, 1991, 128, 1474.

37 Zhu, L. J., Bagchi, M. K., and Bagchi, I. C., Endocrinology, 1995, 136, 4106.

38 Olakanmi, O., McGowan, S. E., Hayek, M. B., and Britigan, B. E., J., Clin. Invest., 1993, 91, 889.

39 Koeppen, A. H., Dickson, A. C., and McEvoy, J. A., J. Neurol. Sci., 1995, 134, (Suppl.), 102.

40 Atkinson, B. G., Blaker, T. W., Tomlinson, J., and Dean, R. L., J. Biol. Chem., 1990, 65, 14156.

41 Terada, L. S., Am. J. Physiol., 1996, 270, H945.

42 Ishimaru, H., Ishikawa, K., Ohe, Y., Takahashi, A., Tatemoto, K., and Maruyama, Y., Brain Res., 1996, 726, 23.

43 Qi, Y., Jamindar, T. M., and Dawson, G., J. Neurochem., 1995, 64, 2458.

44 Sanyal, B., Polak, P. E., and Szuchet, S., J. Neurosci. Res., 1996, 46, 187.

45 Mulvey, M. R., Kuhn, L. C., and Scraba, D. G., J. Biol. Chem., 1996, 271, 9851 .

46 Morris, C. M., Candy, J. M., Oaklely, A. E., Bloxham, C. A., and Edwardson, J. A., Acta Anat. (Basel), 1992, 144, 235.

47 Griffiths, P. D., and Crossman, A. R., Neurosci. Lett., 1996, 211 53.

48 Connor, J. R., and Menzies, S. L., J. Neurol. Sci., 1995, 134, (Suppl.), 33.

49 Connor, J. R., and Menzies, S. L., GLIA, 1996, 17, 83.

50 Mato, M., Oikawa, S., Sakamoto, A., Aokawara, E., Ogawa, T., Mitsuhashi, U., Masuzawa, T., Suzuki, H., Honda, M., Yazaki, Y., Watanabe, E., Luoma, J., Yla-Herttuala, S., Fraser, I., Gordon, S., and Kodama, T., Proc. Natl. Acad. Sci. USA, 1996, 93, 3269.

51 Connor, J. R., Snyder, B. S., Arosio, P., Loeffler, D. A. M., and LeWitt, P., J Neurochem., 1995, 65, 717. 
52 Bouras, C., Giannakopoulos, P., Good, P. F., Hsu, A., Hof, P. R., and Perl, D. P., Eur. Neurol., 1997, 38, 53.

53 Logroscino, G., Marder, K., Graziano, J., Freyer, G., Slavkovich, V., Lolacono, N., Cote, L., and Mayeux, R., Neurology, 1997, 49, 714.

54 Dexter, D. T., Jenner, P., Shapira, A. H., and Marsden, C. D., Ann. Neurol., 1992, 32, (Suppl.), S94.

55 Taylor, T. D., Litt, M., Kramer, P., Pandolfo, M., Angelini, L., Nardocci, N., Davis, S, Pineda, M., Hattori, H., Flett, P. J., Cilio, M. R., Bertini, E., and Hayflick, S. J., Nat. Genet., 1996, 14, 479.

56 Jellinger, K., Paulus, W., Grundke-Iqbal, I., Riederer, P., and Youdim, M. B., J. Neural. Transm. Park. Dis. Dement. Sect., 1990, 2, 327.

57 Grundke-Iqbal, I., Fleming, J., Tung, Y. C., Lassmann, H., Iqbal, K., and Joshi, J., Acta Neuropathol., 1990, 81, 105.

58 Fischer, P., Gotz, M. E., Danielczyk, W., Gsell, W., and Riederer, P., Life Sci., 1997, 60, 2273.

59 Wang, X., Manganaro, F., and Schipper, H. M., J. Neurochem., 1995, 64, 1868.

60 Focht, S. J., Snyder, B. S., Beard, J. L., Van Gelder, W., Williams, L. R., and Connor, J. R., Neuroscience, 1997, 79, 255.

61 Konijn, A. M., Baillieres Clin. Haematol., 1994, 7, 829.

62 ten Kate, J., Wolthuis, A., Westerhuis, B., and van Deursen, C., Eur. J. Clin. Chem. Clin. Biochem., 1997, 35, 53.

63 Herbert, V., Jayatilleke, E., Shaw, S., Rosman, A. S., Giardina, P., Grady, R. W., Bowman, B., and Gunter, E. W., Stem Cells, 1997, 15, 291.

64 Percy, M. E., in Aging and Dementia. Applied Perspectives, ed. Janicki, M. B., and Dalton, A. J., Taylor Francis, New York, 1998, in the press.

65 Dhar, M. S., and Joshi, J. G., Biofactors, 1994, 4, 147.

66 Joshi, J. G., and Clauberg, M., Biofactors, 1988, 1, 207.

67 Percy, M. E., Bauer, S. J., Rainey, S., McLachlan, D. R., Dhar, M. S., and Joshi, J. G., Genome, 1995, 38, 450
68 Sambrook, J., Fritsch, E. F., and Maniatis, T., in Molecular Cloning. A Laboratory Manual, 1989, Cold Spring Harbor Laboratory, Cold Spring Harbor, NY, 2nd edn.

69 Nuovo, G. M., Amplification, 1992, 8, 1

70 Somerville, M. J., Percy, M. E., Bergeron, C., Yoong, L. K., Grima, E. A., and McLachlan, D. R., Brain Res. Mol. Brain Res., 1991, 9, 1 .

71 Altschul, S. F., Gish, W., Miller, W., Myers, E. W., and Lipman, D. J., J. Mol. Biol., 1990, 215, 403.

72 O'Neill, G. P., and Ford-Hutchinson, A. W., FEBS Lett., 1993, 330, 156.

73 Ristimaki, A., Narko, K., and Hla, T., Biochem. J., 1996, 318, 325.

74 Percy, M. E., and Bauer, S. J., unpublished.

75 Munro, H., Nutr. Rev., 1993, 51, 65.

76 Gutteridge, J. M., Ann. N.Y. Acad. Sci., 1994, 738, 201.

77 Vercellotti, G. M., Balla, G., Balla, J., Nath, K., Eaton, J. W., and Jacob, H. S., Artif. Cells Blood Substit. Immobil. Biotechnol., 1996, 22, 207.

78 Tanguay, R. L., and Gallie, D. R., Mol. Cell. Biol., 1996, 16, 146.

79 Dickey, L. F., Wang, Y. H., Shull, G. S., Wortmann, I. A., III, and Theil, E. C., J. Biol. Chem., 1988, 263, 3071.

80 Hentze, M. W., and Kuhn, L. C., Proc. Natl. Acad. Sci. USA, 1996, 93, 8175 .

81 Chou, C. C., Gatti, R. A., Fuller, M. L., Concannon, P., Wong, A., Chada, S., Davis, R. C., and Salser, W. A., Mol. Cell. Biol., 1986, 6, 566. 